\title{
Nitrogen Doses and WeEd Control Via InTeRCROPPING WITH Gliricidia for CoRn Production ${ }^{1}$
}

\author{
Doses de Nitrogênio e Controle de Plantas Daninhas, Através da Consorciação com Gliricídia, \\ para Produção de Milho
}

\author{
SILVA, P.S.L. ${ }^{2}$, BRAGA, J.D. ${ }^{3}$, RIBEIRO, M.S.S. ${ }^{4}$, OLIVEIRA, O.F. ${ }^{5}$ e SANTOS, T.S. ${ }^{6}$
}

\begin{abstract}
Many studies have demonstrated the beneficial influence of nitrogen doses on corn dry grain yield and green ear yield. Due to a growing concern with environmental degradation, many agricultural practices, adopted in the past, are being reexamined. With regard to weed control, strategies that employ mechanical control, including intercrops, are being the object of renewed interest. The purpose of this study was to evaluate the effects of the application of nitrogen doses $\left(0,40,80\right.$, and $120 \mathrm{~kg} \mathrm{~N} \mathrm{ha}^{-1}$, as ammonium sulfate) and weed control on the growth, green ear yield, and grain yield of the AG 1051 corn cultivar. A randomized block experimental design with split-plots and nine replications was adopted. In addition to nitrogen rates, the AG 1051 cultivar was submitted to the following treatments, applied to subplots: no weeding, two hoeings (at 20 and 40 days after sowing), and intercropping with gliricidia (Gliricidia sepium). Gliricidia was sowed at corn planting, between the corn rows, using two seedlings per pit, in pits spaced $0.30 \mathrm{~m}$ apart. Gliricidia did not provide weed control, and gave plant growth, green ear yield and grain yield values similar to the no weeding treatment. However, regarding the number of mature ears got, intercropping with gliricidia did not differ from the two-hoeing treatment. Weed control did not have an effect on plant height and number of marketable, husked green ears, with the application of $120 \mathrm{~kg} \mathrm{~N} \mathrm{ha}^{-1}$, indicating that nitrogen improved the corn's competitive ability. The two-hoeing treatment provided the best means for total green ears weight, number of marketable husked ears, both unhusked and husked marketable ear weight, grain yield and its components than the other treatments. Nitrogen application increased corn growth, green ear yield, and grain yield, as well as weed green biomass, but reduced the stand and growth of gliricidia.
\end{abstract}

Keywords: Zea mays, Gliricidia sepium, ammonium sulfate, green corn, grain yield.

RESUMO - Muitos estudos demonstraram a influência benéfica da aplicação de doses de nitrogênio sobre os rendimentos de grãos e de milho verde. Devido ao crescente interesse sobre a degradação ambiental, muitas práticas agrícolas adotadas no passado estão sendo reexaminadas. No que se refere ao controle de plantas daninhas, estratégias que empregam controle mecânico, incluindo consorciação, estão sendo objeto de renovado interesse. O objetivo deste estudo foi avaliar os efeitos da aplicação de doses de nitrogênio $\left(0,40,80\right.$, and $120 \mathrm{~kg} \mathrm{~N} \mathrm{ha}^{-1}$, como sulfato de amônio) e do controle de plantas daninhas sobre o crescimento e os rendimentos de espigas verdes e de grãos da cultivar de milho AG 1051. Utilizou-se o delineamento experimental de blocos completos casualizados com parcelas subdivididas e nove repetições. Além das doses de nitrogênio, a cultivar AG 1051 foi submetida aos seguintes tratamentos, aplicados às subparcelas: sem capina, duas capinas (aos 20 e 40 dias após a semeadura), e consorciação com gliricídia (Gliricidia sepium). A gliricídia foi semeada por ocasião da semeadura do milho, entre as fileiras da graminea, usando-se duas sementes por cova, em covas distanciadas por 0,30 m. A gliricídia não controlou as plantas daninhas e propiciou crescimento e rendimentos de espigas verdes e grãos similares aos obtidos com a ausência de

Recebido para publicação em 30.8.2009 e na forma revisada em 3.9.2010.

2 Universidade Federal Rural do Semi-Árido - UFERSA, [Brazil, Rural, Federal University of the Semiarid Region], Caixa Postal 137, 59625-900 Mossoró-RN, CNPq fellow, <paulosergio@ufersa.edu.br>; ${ }^{3}$ Student, UFERSA, Mossoró-RN. CNPq fellow, <eng.jefferson@uol.com.br>; ${ }^{4}$ Student, UFERSA, Mossoró-RN, <sauderibeiro@hotmail.com >; ${ }^{5}$ UFERSA (retired professor), Mossoró-RN, <odaci@uol.com.br>; ${ }^{6}$ Student, UFERSA, Mossoró-RN, <tiagronomo_santos19@hotmail.com>.

Planta Daninha, Viçosa-MG, v. 28, n. 3, p. 531-539, 2010 
capinas. Todavia, o número de espigas maduras obtido com a consorciação com a gliricidia não diferiu do obtido com a realização de duas capinas. O controle de plantas daninhas não teve efeito sobre a altura da planta e sobre o número de espigas verdes empalhadas comercializáveis, com a aplicação de $120 \mathrm{~kg} \mathrm{~N} \mathrm{ha}{ }^{-1}$, indicando que o nitrogênio melhorou a capacidade competitiva do milho. A realização de duas capinas proporcionou as maiores médias para o peso total de espigas verdes, número de espigas verdes despalhadas comercializáveis, pesos de espigas verdes empalhadas e despalhadas, comercializáveis, rendimento de grãos e seus componentes, que os demais tratamentos. A aplicação do nitrogênio aumentou o crescimento e os rendimentos de espigas verdes e de grãos do milho, bem como a biomassa verde das plantas daninhas, mas reduziu o estande e o crescimento da gliricidia.

Palavras-chave: Zea mays, Gliricidia sepium, sulfato de amônio, milho verde, rendimento de grãos.

\section{INTRODUCTION}

Many studies have demonstrated the beneficial influence of nitrogen doses on corn dry grain yield (Kamara et al., 2005, for example) and green ear yield (Silva et al., 2003). In addition to this beneficial effect, studies on nitrogen doses have still been interesting for researchers since the response provided by nitrogen on corn yield depends on both genotypic (Kamara et al., 2005) and environmental influences (Vetsch \& Randall, 2004).

Herbicides provide many advantages, including application efficiency and weed control efficiency, good cost effectiveness, and selectivity (Deuber, 2006). However, in many countries, an increased interest in physical and cultural weed control methods (Balbinot Jr \& Fleck, 2005; Moraes et al., 2009), including the use of intercrops (Borghi et al., 2008; Silva et al., 2009), has been observed in the past two decades (Melander et al., 2005). Such interest has been created due to soil and water pollution by agrochemicals, which in some countries has been mainly caused by the use of herbicides (Spliid \& Koeppen, 1998). In addition to environmental pollution, herbicide use may contribute towards an impoverishment of the fauna and flora (Marshall et al., 2003), and human consumption of herbicide residues via contaminated water and foods. Furthermore, the extensive use of herbicides has resulted in the selection of weed biotypes that are resistant to these products (Christoffoleti \& López-Ovejero, 2003).

Multipurpose trees are being used more and more, in tropical countries, for degraded area recovery, soil improvement in fallow areas, and erosion control. As an alternative to existing cropping systems in the tropics, growers are encouraged to adopt agroforestry systems in which trees, when pruned, contribute their branches that can be used as soil mulching in associated crops. Gliricidia sepium, Leucaena leucocephala, and Senna siamea are trees extensively tested for agroforestry technologies (Kamara et al., 2000). However, in addition to improving the soil, they provide material that serves as soil mulch and also suppresses weed growth. Weed growth in alley cultivations can be suppressed because the canopy becomes closed. However, in addition to the physical suppression exerted on weeds, plant residue decomposition may also release phytotoxic compounds that inhibit the crop as well as the weed growth. Plant species are different as regards to their response to phytotoxic residues. The use of G. sepium, as soil mulch, did not have an allelopathic effect on corn and bean, but it significantly decreased the population of some weed species (Obando, 1987). Soil mulching, with $G$. sepium and $S$. siamea, reduced weed density and biomass, while mulching with L. leucocephala had a more limited effect on the reduction of those traits (Kamara et al., 2000).

Studies on effects of nitrogen application and weed control were performed by several authors (Evans et al., 2003; Zanatta et al., 2007; Chikoye et al., 2008; Rizzardi et al, 2008). The application of nitrogen results in larger leaf area, biomass and height, which improves the competitive ability of corn against weeds (Evans et al., 2003). That effect of the nitrogen depends upon the location, cultivar, nitrogen dose (Chikoye et al., 2008) and application time (Rizzardi et al., 2008). 
This study made research about a new type of intercropping, that is, the use of a legume tree in order to control weeds in corn. No data were found in the consulted literature comparing soil mulching and intercropping in corn. In rice, it was observed that the application of wheat residues as soil mulch and intercropping with Sesbania rostrata were equally effective in controlling weeds (Singh et al., 2007). There have been recent indications that gliricidia intercropped with corn (Silva et al., 2009), planted at a $0.50 \mathrm{~m}$ spacing between rows in both crops, does control weeds.

The objective of this study was to evaluate the effects of the application of nitrogen doses and weed control, via intercropping with gliricidia, on the growth, green ear yield, and grain yield of AG 1051 corn cultivar.

\section{MATERIAL AND METHODS}

The studies were performed at Fazenda Experimental "Rafael Fernandes" (Experimental Farm), (latitude $5^{\circ} 11^{\prime} \mathrm{S}$, longitude $37^{\circ} 20^{\prime} \mathrm{W}$, and $18 \mathrm{~m}$ elevation). According to Gaussen's bioclimatic classification, the climate in the region is classified as type 4th, or distinctly xerothermic, which means tropical hot with a pronounced, long dry season, lasting from seven to eight months and with a xerothermic index between 150 and 200. The mean maximum temperature in the region is between 32.1 and $34.5^{\circ} \mathrm{C}$, with June and July as the coolest months, while the mean annual rainfall is around $825 \mathrm{~mm}$ (Carmo Filho \& Oliveira, 1989). Insolation increases from March to October, with a mean of $241.7 \mathrm{~h}$; the maximum relative humidity reaches $78 \%$ in April while the minimum is $60 \%$ in September.

The soil, in the experiment area, was classified as Eutrophic Red-Yellow Argisol according to the Brazilian Soil Classification System (Embrapa [Brazilian, Governmental Company of Agricultural-Cattle Breeding Research], 1999), and as Ferric Lixisol according to the Soil Map of the World (FAO, 1988); it was analyzed and it showed the following results: $\mathrm{pH}=6.40 ; \mathrm{P}=23.40 \mathrm{mg} \mathrm{dm}^{-3}$; $\mathrm{K}^{+}=0.21 \mathrm{cmol}_{\mathrm{c}} \mathrm{dm}^{-3} ; \mathrm{Ca}^{2+}=2.30 \mathrm{cmol}_{\mathrm{c}} \mathrm{dm}^{-3}$; $\mathrm{Mg}^{2+}=1.20 \mathrm{cmol}_{\mathrm{c}} \mathrm{dm}^{-3} ; \mathrm{Al}^{3+}=0.00 \mathrm{cmol}_{\mathrm{c}} \mathrm{dm}^{-3}$;
$\mathrm{Na}^{+}=0.28 \mathrm{cmol}_{\mathrm{c}} \mathrm{dm}^{-3} ;$ organic matter $=$ $0.98 \mathrm{~g} \mathrm{~kg}^{-1}$; and Sum of bases $=3.99 \mathrm{cmol}_{\mathrm{c}} \mathrm{dm}^{-3}$. Weed control in this area, where corn or cowpea (Vigna unguiculata) were previously grown, has always been achieved by means of two hoeings, performed at 20 and 40 days after sowing.

The soil was tilled by means of two harrowings and received $1 / 3$ of total $\mathrm{N}$ applied, $60 \mathrm{~kg} \mathrm{P}_{2} \mathrm{O}_{5}$, and $30 \mathrm{~kg} \mathrm{~K} \mathrm{O}_{2}$ per ha as planting fertilization. The remaining $\mathrm{N}$ was applied in equal parts after each hoeing. Ammonium sulfate, single superphosphate, and potassium chloride were used as sources of $\mathrm{N}, \mathrm{P}_{2} \mathrm{O}_{5}$, and $\mathrm{K}_{2} \mathrm{O}$, respectively. Plant rows were spaced $1.0 \mathrm{~m}$ apart, and pits in the same row were spaced $0.40 \mathrm{~m}$. apart. Seeding was accomplished by using four seeds per pit. A thinning operation was performed 20 days after planting, leaving the two more vigorous plants in each pit; the experiment was thus left with a programmed planting density of 50 thousand plants ha ${ }^{-1}$.

The fall armyworm (Spodoptera frugiperda), the crop's main pest in the region, was controlled with sprays of 0,0-diethyl-0,3,5,6trichloro-2-pyridinyl thiophosphate $\left(0.4 \mathrm{~L} \mathrm{ha}^{-1}\right)$.

The experiment was sprinkler-irrigated, with experimental plots being perpendicularly arranged in relation to the row of sprinklers. The water depth required for corn $(5.3 \mathrm{~mm})$ was calculated considering an effective depth of the root system of $0.40 \mathrm{~m}$. Irrigation time was based on the water retained by the soil at a tension of $0.40 \mathrm{Mpa}$. Irrigations were performed three times a week, beginning after planting, and were suspended after the green corn was harvested.

A randomized block experimental design in split-plots, with nine replicates, was adopted. Each subplot consisted of four rows, each row had a $6.0 \mathrm{~m}$ length. The usable area was considered as the space occupied by the two central rows; one pit at each end of each row was eliminated. AG 1051 corn cultivar was submitted to nitrogen doses $(0,40,80$, and $120 \mathrm{~kg} \mathrm{~N} / \mathrm{ha}$ ), in addition to the following treatments applied to the subplots: no weeding, two hoeings (at 20 and 40 days after planting), and intercropping with gliricidia. Weedings were performed with a hoe, and the same 
employee was assigned to render the service at each block. In the intercropping treatment, gliricidia was sowed at corn planting, between the corn rows, using two seeds per pit, in pits spaced $0.30 \mathrm{~m}$ apart.

Plant height and ear height were measured in all plants of the usable area of each subplot after the green corn was harvested for the last time. The distance from ground level to the point of insertion of the tallest leaf blade was considered as plant height; ear height was measured from ground level up to the base of the tallest ear (first ear, in the case of prolific plants).

Green corn yield was evaluated by the total number and weight of ears, and the number and weight of marketable ears, both unhusked and husked. Marketable unhusked ears were considered as those with an appearance suitable for commercialization and a length equal to or above $22 \mathrm{~cm}$. Marketable husked ears were considered as those ones that showed health and grain set suitable for commercialization, and length equal to or above $17 \mathrm{~cm}$. Evaluations were made in mature corn for grain yield and its components. The ears produced in the usable area of each subplot were harvested when the grain achieved a water content of about $20 \%$, and they were then placed to become dry and, subsequently, they were threshed out. The numbers of ears thus obtained and their grains allowed to estimate number of ears per hectare and grain yield. Number of kernels per ear was estimated based on the kernels counted in ten of those ears. 100-grain weight was obtained from five samples.

After harvesting the dry corn, the weeds found in a $1.0 \mathrm{~m} \mathrm{x} 1.0 \mathrm{~m}$ area, established at random in the central part of the plot, were cut even with the ground, identified, and weighed. At the same time, the gliricidia plants, present in the area between the two central rows of each experimental unit, were counted, cut even with the ground, weighed, and measured. Therefore, gliricidia plant height was considered as the distance from ground level up to the top of each plant.

The data were submitted to analysis of variance by using the SAEG software (Ribeiro Júnior, 2001), while the Table Curve software
(Jandel Scientific, 1992) was used for the regression analyses. The data were submitted to the variance homogeneity test before performing the statistical analyses (Bartlett, 1937). Before carrying out the analysis of variance, because weed counts had a tendency to follow the Poisson distribution, the corresponding data were transformed to square root (Bartlett, 1947). A regression equation was selected based on the following criteria: biological explanation of the phenomenon observed, simplicity of the equation, significance of the coefficients at $5 \%$ probability by Student's $t$ test, and coefficient of determination value.

\section{RESULTS AND DISCUSSION}

Twenty-three weed species grew in the experiment (Table 1). This number is higher than those ones observed by other authors, in similar studies performed in the same region (Gomes et al., 2007). There was a significant variation in the growth of those species in the experimental units. Alternanthera tenella, Commelina sp., and Cucumis anguria were the

Table 1 - Index of occurrence (number of plots where a given weed species occurred/total number of experimental plots) of weed species identified in the experiment

\begin{tabular}{|l|c|}
\hline \multicolumn{1}{|c|}{ Species name } & $\begin{array}{c}\text { Occurrence } \\
\text { index (\%) }\end{array}$ \\
\hline Alternanthera tenella Colla & 88.0 \\
\hline Amaranthus viridis L. & 20.4 \\
\hline Blainvillea aemella (L.) Philipson & 15.7 \\
\hline Borreria verticillata (L.) G. Mey & 1.9 \\
\hline Cenchrus echinatus Steud. ex Döll & 25.9 \\
\hline Centrosema pascurorum Mart. ex Benth. & 0.9 \\
\hline Commelina sp. & 80.6 \\
\hline Corchorus hirtus L. & 4.6 \\
\hline Croton lobatus L. & 1.9 \\
\hline Cucumis anguria L. & 76.9 \\
\hline Desmanmthus virgatus (L.) Willd. & 13.9 \\
\hline Desmodium globarum (Mill.) DC & 3.7 \\
\hline Digitaria sanguinalis (L.) Scop. & 13.9 \\
\hline Herissantia crispa (L.) Brizicky & 4.6 \\
\hline Ipomoea sp. & 9.3 \\
\hline Macroptilium martii (Benth.) & 0.9 \\
\hline Merremia aegyptia (L.) Urb. & 13.9 \\
\hline Phyllanthus amarus Schum. et Thonn. & 4.6 \\
\hline Physalis angulata L. & 5.6 \\
\hline Senna occidentalis (L.) Link & 1.9 \\
\hline Senna uniflora (P. Mill.) H.S. Irwin \& Barneby & 1.9 \\
\hline Spigelia sp. & 2.7 \\
\hline Waltheria indica L. & 0.9 \\
\hline
\end{tabular}


species with the highest growth in most experimental units. The weed population that grows in a given area depends on several factors, and although the population comprises different species, few of them are predominant, and correspond from 70 to $90 \%$ of the species total (Buhler, 1999).

No effect was found for the interaction between weed control methods $\mathrm{x}$ nitrogen doses on green matter of the above-ground part of weeds and corn ear height. However, such interaction was verified for plant height. The two-hoeing treatment provided lower weed green biomass and higher corn ear height values than the other two treatments, which were not different from each other (Table 2). A similar fact was observed for plant height, but only regarding the three lowest nitrogen doses, since no differences were observed among the three treatments at the highest nitrogen dose (Table 2). Plant height and ear height reductions caused by weeds have been observed by other authors (Silva et al., 2004a), but this has not always been the case (Gomes et al., 2007).

As regards to the total numbers of ears and marketable husked ears, and total ear weight, and both unhusked and husked marketable ear weight, no effect was observed for the interaction of weed control methods $\mathrm{x}$ nitrogen doses. However, such interaction occurred for a number of marketable unhusked ears. No differences were observed between weed control methods, for total number of green ears and number of marketable unhusked ears, with the application of the highest nitrogen dose (Table 3). With regard to the other traits employed to evaluate green ear yield, two hoeings provided higher means than the other two treatments, which were not different from each other (Table 3). Green ear yield reductions, due to the presence of weeds and intercropping, being similar to those ones observed in the present work, have been observed by other authors (Gomes et al., 2007) who studied the corn - cowpea intercropping system in order to reduce weeds in corn.

The two-hoeing treatment provided higher means for grain yield and its components than the other treatments (no weeding or intercropping with gliricidia), which were not different from each other (Table 4). Although some recent indications exist that gliricidia intercropped with corn (Silva et al., 2009) controls weeds, this was not observed in the present work, except for a number of mature ears (Table 4), in which intercropping with gliricidia did not differ from the two-hoeing treatment. The identification of factors that either contribute or not towards weed control, via intercropping, becomes difficult because the competitive relationship between the crop and the weeds, in an agroecosystem, is determined by climatic, edaphic, biological, and cultural factors (Altieri \& Liebman, 1988).

The weeds reduced most of the evaluated characteristics in this study (Tables 2, 3 and 4). Weeds reduced crop yield by competing with corn for water, nutrients and light. But another aspect must be involved. Corn root system is less developed with weed presence (Thomas \& Allison, 1975). Thus, a smaller corn root

Table 2 - Mean green matter values of the above-ground part of weeds, ear height, and plant height of AG 1051 corn cultivar, as a function of weed control method and application of nitrogen doses

\begin{tabular}{|c|c|c|c|c|c|c|}
\hline \multirow{3}{*}{$\begin{array}{l}\text { Weed control } \\
\text { method }\end{array}$} & \multirow{3}{*}{$\begin{array}{c}\text { Green matter of the } \\
\text { above-ground part of } \\
\text { weeds }\left(\mathrm{g} \mathrm{m}^{-2}\right)\end{array}$} & \multirow{3}{*}{$\begin{array}{c}\begin{array}{c}\text { Ear height } \\
(\mathrm{cm})\end{array} \\
\begin{array}{c}\text { Means of four nitrogen } \\
\text { doses }\end{array}\end{array}$} & \multicolumn{4}{|c|}{$\begin{array}{l}\text { Plant height } \\
\text { (cm) }\end{array}$} \\
\hline & & & \multicolumn{4}{|c|}{ Nitrogen doses $\left(\mathrm{kg} \mathrm{ha}^{-1}\right)$} \\
\hline & & & 0 & 40 & 80 & 120 \\
\hline Two hoeings & $220.4 \mathrm{~b}$ & $92 \mathrm{a}$ & $147 \mathrm{a}$ & $178 \mathrm{a}$ & $177 \mathrm{a}$ & $182 \mathrm{a}$ \\
\hline With G. sepium & $1887.3 \mathrm{a}$ & $82 \mathrm{~b}$ & $123 \mathrm{~b}$ & $156 \mathrm{~b}$ & $165 \mathrm{~b}$ & $177 \mathrm{a}$ \\
\hline No weeding & $2185.9 \mathrm{a}$ & $86 \mathrm{~b}$ & $132 \mathrm{~b}$ & $158 \mathrm{~b}$ & $170 \mathrm{~b}$ & $180 \mathrm{a}$ \\
\hline $\mathrm{CVb}, \%$ & 39.5 & 10.3 & \multicolumn{4}{|c|}{5.9} \\
\hline
\end{tabular}

${ }^{1}$ In the columns, means followed by the same letter do not differ from one another at $5 \%$ probability by Tukey's test. CVb $=$ coefficient of experimental variation corresponding to subplots. 
Table 3 - Means for traits employed to evaluate green corn yield, as a function of weed control method and application of nitrogen doses, in AG 1051 corn cultivar

\begin{tabular}{|c|c|c|c|c|c|c|c|c|c|}
\hline \multirow{4}{*}{$\begin{array}{l}\text { Weed control } \\
\text { method }\end{array}$} & \multicolumn{2}{|c|}{ Green ear totals $\mathrm{ha}^{-1}$} & \multicolumn{5}{|c|}{ Marketable unhusked green ears $\mathrm{ha}^{-1}$} & \multicolumn{2}{|c|}{$\begin{array}{l}\text { Marketable husked } \\
\text { green ears }\end{array}$} \\
\hline & \multirow{2}{*}{ Number } & \multirow{2}{*}{$\begin{array}{l}\text { Weight } \\
(\mathrm{kg})\end{array}$} & \multicolumn{4}{|c|}{ Number } & \multirow{2}{*}{$\begin{array}{l}\text { Weight } \\
(\mathrm{kg})\end{array}$} & \multirow{2}{*}{ Number } & \multirow{2}{*}{$\begin{array}{l}\text { Weight } \\
(\mathrm{kg})\end{array}$} \\
\hline & & & \multicolumn{4}{|c|}{ Nitrogen doses $\left(\mathrm{kg} \mathrm{ha}^{-1}\right)$} & & & \\
\hline & \multicolumn{2}{|c|}{$\begin{array}{c}\text { Means of four nitrogen } \\
\text { doses }\end{array}$} & 0 & 40 & 80 & 120 & \multicolumn{3}{|c|}{ Means of four nitrogen doses } \\
\hline Two hoeings & $49161 \mathrm{a}$ & $11966 \mathrm{a}$ & $33967 \mathrm{a}$ & $45778 \mathrm{a}$ & $46478 \mathrm{a}$ & $47456 \mathrm{a}$ & $11394 \mathrm{a}$ & $34242 \mathrm{a}$ & $6216 \mathrm{a}$ \\
\hline With G. sepium & $49622 \mathrm{a}$ & $8234 \mathrm{~b}$ & $10144 \mathrm{~b}$ & $29667 \mathrm{~b}$ & $37733 \mathrm{~b}$ & $46278 \mathrm{a}$ & $6776 \mathrm{~b}$ & $17503 \mathrm{~b}$ & $2896 \mathrm{~b}$ \\
\hline No weeding & $49391 \mathrm{a}$ & $8289 \mathrm{~b}$ & $13200 \mathrm{~b}$ & $26711 \mathrm{~b}$ & $39567 \mathrm{~b}$ & $44167 \mathrm{a}$ & $6742 \mathrm{~b}$ & $17349 \mathrm{~b}$ & $2798 \mathrm{~b}$ \\
\hline $\mathrm{CVb}, \%$ & 10.2 & 21.1 & \multicolumn{4}{|c|}{20.6} & 26.4 & 35.6 & 39.7 \\
\hline
\end{tabular}

${ }^{1 /}$ In the columns, means followed by the same letter do not differ from one another at $5 \%$ probability by Tukey's test. CVb $=$ coefficient of experimental variation corresponding to subplots.

Table 4 - Means for grain yield and its components, as a function of weed control method and application of nitrogen doses, in AG 1051 corn cultivar

\begin{tabular}{|c|c|c|c|c|c|c|c|}
\hline \multirow{3}{*}{$\begin{array}{l}\text { Weed control } \\
\text { method }\end{array}$} & \multicolumn{4}{|c|}{ Number of kernels per ear } & Number of mature & 100-kernel weight & Grain yield \\
\hline & \multicolumn{4}{|c|}{ Nitrogen doses $\left(\mathrm{kg} \mathrm{ha}^{-1}\right)$} & \multirow{2}{*}{\multicolumn{3}{|c|}{ Means of four nitrogen doses }} \\
\hline & 0 & 40 & 80 & 120 & & & \\
\hline Two hoeings & $291.5 \mathrm{a}$ & $423.2 \mathrm{a}$ & $407.4 \mathrm{a}$ & $458.3 \mathrm{a}$ & $48040 \mathrm{a}$ & $26.2 \mathrm{a}$ & $4763 \mathrm{a}$ \\
\hline With G. sepium & $162.6 \mathrm{~b}$ & $249.4 \mathrm{~b}$ & $333.0 \mathrm{~b}$ & $394.5 \mathrm{~b}$ & $45471 \mathrm{ab}$ & $23.3 \mathrm{~b}$ & $3047 \mathrm{~b}$ \\
\hline No weeding & $183.1 \mathrm{~b}$ & $276.3 \mathrm{~b}$ & $338.5 \mathrm{~b}$ & $388.5 \mathrm{~b}$ & $44807 \mathrm{~b}$ & $23.1 \mathrm{~b}$ & $2897 \mathrm{~b}$ \\
\hline $\mathrm{CVb}, \%$ & \multicolumn{4}{|c|}{15.9} & 10.5 & 8.0 & 25.2 \\
\hline
\end{tabular}

${ }^{1 /}$ In the columns, means followed by the same letter do not differ from one another at $5 \%$ probability by Tukey's test. CVb $=$ coefficient of experimental variation corresponding to subplots.

system, due to weed presence, would be less efficient in nutrient absorption. Water content in corn plots with weeds was larger than in the crop plots without weeds (Thomas \& Allison, 1975). Development of water stress symptoms, with the presence of weeds, may not be caused by water availability, but by the reduced ability to absorb water through the root system. Therefore, despite the fact that the experiment, on which this study was based, used irrigation, the reduction in the corn root system, caused by the weeds, would reduce water absorption capacity. Water deficiency induces the closing of stomata thus paralyzing photosynthesis and drastically reducing production in corn competing with weeds (Silva et al., 2004b). This problem is aggravated if there are $\mathrm{C}_{4}$ weeds in the area, such as the Cenchrus echinatus (Table 1) that like corn, have high efficiency in water use (Silva et al., 2004b). Another possibility would be that the invader root exudates, what could inhibit corn root growth (Rajcan \& Swanton, 2001).

Two components are involved in the competition for light: the quantity and the quality of light. The quantitative component of light determines photosynthetic activity, whereas the quality of light influences plant morphology. An important characteristic of the corn is that most of the light is intercepted by the younger, more efficient leaves above the ear and less than $10 \%$ of the photon flux density (PFD) reaches the leaves below $1 \mathrm{~m}$. Thus, direct competition for PFD between corn and weeds is relatively small. The leaf area index (LAI) defines the ability of a plant to intercept PFD and it is an important determining factor for the accumulation of dry matter. A high degree of competition with weeds was seen (Tollenaar et al., 1994) reducing corn LAI at blooming by $15 \%$. Thus, grain yield loss, resulting from competition for 
light, is best explained through the reduction in LAI than in lower photosynthetic rates of shaded leaves (Rajcan \& Swanton, 2001).

The lower leaves are not only exposed to a reduced amount of $\mathrm{PFD}$, but they also receive a quality of light that differs from the total sunlight received by the upper leaves. The light within the crown is rich in far red radiation, FR (730 at $740 \mathrm{~nm})$. This is caused by the selective absorption of red light, $\mathrm{R}(660-670 \mathrm{~nm})$ by photosynthetic pigments and the reflection of FR light by green leaves. This makes the far-red/red (FR/R) ratio being higher in the lower part of the crown than in the upper part of the crown. Although weeds generally do not shade corn, there are indications that corn grown in the presence of weeds receives a greater $F R / R$ ratio than the weed free crop (Rajcan \& Swanton, 2001).

The application of increased nitrogen doses increased weed green biomass (Table 5). The effects of increased nitrogen doses on weed biomass are not consistent. Nitrogen can have a positive, null, or negative influence on weed biomass, which may suggest that several factors, including weed species and the crop associated with them, may be involved in the process (Chykoye et al., 2008). It is interesting to point out that, at the highest dose, nitrogen eliminated the negative interference of weeds on plant height (Table 2) and the number of marketable unhusked ears (Table 3). This effect of nitrogen, which has been also observed by other authors (Evans et al., 2003; Zanatta et al., 2007), indicates that the application of nitrogen improves the competitive ability of corn against weeds.

Nitrogen application reduced gliricidia density in the experimental units, as well as gliricidia growth (Table 5). Differently from this result, other researches have indicated that the application of increasing nitrogen doses positively influenced growth, at least in some legumes (Marques et al., 2006). Possibly, the observed reductions in density and growth of this legume are the result of higher corn

Table 5 - Effects of the application of nitrogen doses on weed green biomass, gliricídia traits and AG 1051 corn cultivar traits grown with (two hoeings or intercropped with G. sepium) or without weed control

\begin{tabular}{|c|c|c|c|c|}
\hline Traits & $\begin{array}{l}\text { Weed control } \\
\text { methods }\end{array}$ & Fitted regression equation ${ }^{1 /}$ & $R^{2}$ & $\mathrm{CVa}$ \\
\hline Green weed biomass $\left(\mathrm{g} \mathrm{m}^{-2}\right)$ & All & $y=1106.0-0.000044 x^{3}+53.46 x^{0.5}$ & 0.99 & 39.5 \\
\hline Number of gliricidia plants $\mathrm{m}^{-2}$ & With G. sepium & $\mathrm{y}=4.94-0.0234 \mathrm{x}$ & 0.95 & 24.3 \\
\hline Gliricidia plant height $(\mathrm{cm})$ & With G. sepium & $\mathrm{y}^{-1}=0.01327+0.0001 \mathrm{x}$ & 0.99 & 17.8 \\
\hline \multirow{2}{*}{ Dry matter of above-ground part of gliricidia (g per plant) } & With G. sepium & $\mathrm{y}^{-1}=0.0681+0.0027 \mathrm{x}$ & 0.99 & 51.9 \\
\hline & Two hoeings & $y=147.17-0.305 x+6.43 x^{0.5}$ & 0.99 & \\
\hline \multirow{2}{*}{ Corn plant height $(\mathrm{cm})$} & With G. sepium & $\mathrm{y}=123.45+4.85 \mathrm{x}^{0.5}$ & 0.99 & 8.8 \\
\hline & No weeding & $\mathrm{y}=131.53+4.38 \mathrm{x}^{0.5}$ & 0.99 & \\
\hline Ear height $(\mathrm{cm})$ & All & $\mathrm{y}=66.18+3.14 \mathrm{x}^{0.5}$ & 0.99 & 14.5 \\
\hline Total number of ears & All & $y=48881.8+0.53 x^{2}-0.0043 x^{3}$ & 0.97 & 9.2 \\
\hline \multirow{2}{*}{ Total ear weight $\left(\mathrm{kg} \mathrm{ha}^{-1}\right)$} & All & $\mathrm{y}=6299.4+53.27 \mathrm{x}$ & 0.98 & 22.0 \\
\hline & Two hoeings & $\mathrm{y}=34013.33-129.49 \mathrm{x}+2619.97 \mathrm{x}^{0.5}$ & 0.99 & \\
\hline \multirow{2}{*}{ Number of marketable unhusked ears ha ${ }^{-1}$} & With G. sepium & $y^{2}=108476000+17097600 x$ & 0.99 & 18.9 \\
\hline & No weeding & $\mathrm{y}=12898.0+377.0 \mathrm{x}-0.0080 \mathrm{x}^{3}$ & 0.99 & \\
\hline Weight of marketable unhusked ears $\left(\mathrm{kg} \mathrm{ha}^{-1}\right)$ & All & $y^{2}=12961400+1098820 x$ & 0.99 & 26.8 \\
\hline Number of marketable husked ears ha ${ }^{-1}$ & All & $y^{2}=81096500+8864930 x$ & 0.98 & 31.2 \\
\hline Weight of marketable husked ears $\left(\mathrm{kg} \mathrm{ha}^{-1}\right)$ & All & $y=1514.10+40.93 x$ & 0.97 & 38.6 \\
\hline \multirow{2}{*}{ Number of mature ears ha ${ }^{-1}$} & All & $\mathrm{y}=44120.3+33.1 \mathrm{x}$ & 0.96 & 10.4 \\
\hline & Two hoeings & $\mathrm{y}=297.1+14.9 \mathrm{x}^{0.5}$ & 0.98 & \\
\hline \multirow{2}{*}{ Number of kernels per ear } & With G. sepium & $\mathrm{y}^{2}=25077.3+1060.5 \mathrm{x}$ & 0.99 & 19.2 \\
\hline & No weeding & $\mathrm{y}^{2}=34219.4+995.4 \mathrm{x}$ & 0.99 & \\
\hline 100-kernel weight (g) & All & $\mathrm{y}=22.0+0.036 \mathrm{x}$ & 0.98 & 13.9 \\
\hline Grain yield $\left(\mathrm{kg} \mathrm{h}^{-1}\right)$ & All & $y=2046.0+25.4 x$ & 0.99 & 35.9 \\
\hline
\end{tabular}

${ }^{1 /}$ All coefficients were significant at $5 \%$ probability by Student's $\mathrm{t}$ test. CVa $=$ coefficient of experimental variation corresponding to plots 
growth (Table 5) as a response to increased doses of applied nitrogen. Such higher growth would have resulted in more competition over gliricidia. The argument can be submitted that if weeds benefited from nitrogen (Table 5), gliricidia may also benefit from nitrogen fertilization. However, it should be kept in mind that gliricidia was planted at half the distance between two corn rows, while the weeds occupied the entire area between two corn rows. Therefore, it is possible that weeds benefited more from applied nitrogen than gliricidia. Anyway, this subject deserves to be studied in more depth.

The increase in applied nitrogen doses also increased corn growth, green ear yield, and grain yield (Table 5). The beneficial effect of nitrogen on green ear yield and grain yield has also been observed by other authors (Silva et al., 2003). In the present research, nitrogen response was linear regarding total weight, marketable unhusked ear weight, and grain yield, indicating that doses higher than $120 \mathrm{~kg} \mathrm{~N} \mathrm{ha}^{-1}$ can provide higher yields. The benefits from nitrogen fertilization would result from the effect of nitrogen on several processes in corn. Reductions in nitrogen availability cause reductions in the rate at which leaves appear, leaf area (Cathcart \& Swanton, 2004), and the longevity and photosynthetic activity of those leaves (Subedi $\& \mathrm{Ma}, 2005)$. In addition, the lack of nitrogen delays female flowering (Cathcart \& Swanton, 2004), the architecture and morphology of the root system (Duriex et al., 1994), and biomass partition dynamics (Evans et al., 2003) in corn.

Therefore, it can be concluded that gliricidia did not provide weed control, and gave plant growth, green ear yield and grain yield values similar to the no weeding treatment. However, for a number of mature ears, intercropping with gliricidia did not differ from the two-hoeing treatment. Weed control did not have an effect on plant height and number of marketable, husked green ears, with the application of $120 \mathrm{~kg} \mathrm{~N} \mathrm{ha}$, indicating that nitrogen improved the corn's competitive ability. The two-hoeing treatment provided higher means as regards to total ear weight, number of marketable husked ears, both unhusked and husked marketable ear weight, grain yield and its components than the other treatments. Nitrogen increased corn growth, green ear yield, and grain yield, as well as weed green biomass, but reduced the stand and growth of gliricidia plants.

\section{LITERATURE CITED}

ALTIERI, M. A.; LIEBMAN, M. Weed management: ecological guidelines. In: ALTIERI, M.A.; LIEBMAN, M. (Eds.). Weed management in agroecosystems: ecological approaches. Boca Raton: CRC, 1988. 354 p.

BALBINOT JR., A. A.; FLECK, N. G. Competitividade de dois genótipos de milho (Zea mays) com plantas daninhas sob diferentes espaçamentos entre fileiras. Planta Daninha [Weeds], v. 23, n. 3, p. 415-421, 2005.

BARTLETT, M. S. Some examples of statistical methods of research in agriculture and applied biology. J. Royal Stat. Soc., v. 4, n. 1, p. 137-183, 1937.

BARTLETT, M. S. The use of transformations. Biometrics, v. 3 , n. 1, p. 39-52, 1947

BORGHI, E. et al. Influência da distribuição espacial do milho e da Brachiaria brizantha consorciados sobre a população de plantas daninhas em sistema de plantio direto na palha.

Planta Daninha, v. 26, n. 3, p. 559-568, 2008.

BUHLER, D. D. Weed population responses to weed control practices. I. Seed bank, weed populations, and crop yields. Weed Sci., v. 47, n. 4, p. 416-422, 1999.

CARMO FILHO, F. \& OLIVEIRA, O. F. Mossoró: um município do semi-árido nordestino. Mossoró: Guimarães Duque Foundation/ ESAM, 1989. 62 p. (Mossoroense Collection, Series B., 672)

CATHCART, R. J.; SWANTON, C. J. Nitrogen and green foxtail (Setaria viridis) competition effects on corn growth and development. Weed Sci., v. 52, p. 1039-1049, 2004.

CHIIKOYE, D. et al. Response of corn genotypes to weed interference and nitrogen in Nigeria. Weed Sci., v. 56, p. 424-433, 2008.

CHRISTOFFOLETI, P. J.; LÓPEZ-OVEJERO, R. Principais aspectos da resistência de plantas daninhas ao herbicida glyphosate. Planta Daninha, v. 21, n. 3, p. 507-515, 2003.

DEUBER, R. Métodos de manejo das plantas infestantes [Handling methods of the infesting plants]. In: DEUBER, R. Ciência das plantas infestantes: fundamentos [Science of the infesting plants: fundamentals]. Jaboticabal: FUNEP, 2006. p. $106-148$ 
DURIEUX, R. P. et al. Root distribution of corn: the effect of N fertilization. Agron. J., v. 86, n. 6, p. 958-962, 1994.

EVANS, S. P. et al. Nitrogen application influences the critical period for weed control in corn. Weed Sci., v. 51, p. 408-417, 2003.

EMPRESA BRASILEIRA DE PESQUISAAGROPECUÁRIA - EMBRAPA. Centro Nacional de Pesquisa do Solo. Sistema brasileiro de classificação de solos. Brasília: Serviço de Produção de Informação, 1999. 412 p.

FAO. Soil map of the world: revised legend. Rome: UNESCO, 1988. 119 p.

GOMES, J. K. O. et al. Effects of weed control through cowpea intercropping on maize morphology and yield. Planta Daninha, v. 25, n. 3, p. 433-441, 2007.

JANDEL SCIENTIFIC. Table Curve 3.0: curve fitting software. Corte Madera: 1992. 280 p.

KAMARA, A. Y. et al. Selective control of weeds in an arable crop by mulches from some multipurpose trees in

Southwestern Nigeria. Agrof. Syst., v. 50, n. 1, p. 17-26, 2000.

KAMARA, A. Y. et al. Performance of diverse maize genotypes under nitrogen deficiency in the Northern Guinea Savanna of Nigeria. Exper. Agric., v. 41, n. 2, p. 199-212, 2005.

MARQUES, V. B. et al. Efeito de fontes e doses de nitrogênio sobre o crescimento inicial e qualidade de mudas de jacarandáda-Bahia (Dalbergia nigra (Vell.) Fr. All. Ex Benth.).

R. Árvore, v. 30, n. 5, p. 725-735, 2006.

MELANDER, B.; RASMUSSEN, I. A.; BÀRBERI, P. Integrating physical and cultural methods of weed control examples from European research. Weed Sci., v. 53, p. 369-381, 2005.

MARSHALL, E. J. P. et al. The role of weeds in supporting biological diversity within crop fields. Weed Res., v. 43, n. 2 , p. $77-89,2003$.

MORAES, P. V. D. et al. Manejo de plantas de cobertura no controle de plantas daninhas na cultura do milho.

Planta Daninha, v. 27, n. 2, p. 289-296, 2009.

OBANDO, L. Potencial alelopatico de Gliricidia sepium (Jacq.) Walp. sobre los cultivos de maiz y frijol y las malezas predominantes. In: WITHINGTON, D.; GLOVER, N.; BREWBAKER, J. L. (Eds.). Gliricidia sepium (Jacq.) Walp.: management and improvement. In: INTERNACIONAL WORKSHOP AT CENTRO AGRONOMICO TROPICAL DE INVESTIGACION Y ENSEÑANZA (CATIE), 1987, Turrialba, Costa Rica. Proceedings ... Wiamanalo: Nitrogen Fixing Tree Association (NFTA), 1987. p. 59-60. (Special NFTA Publication, 87-01).
RA JCAN, I., SWANTON, C. J. Understanding maize-weed competition: resource competition, light quality and the whole plant. Field Crops Res., v. 71, n. 2, p. 139-150, 2001.

RIBEIRO JÚNIOR, J. I. Análise estatísticas no SAEG. Viçosa, MG: Universidade Federal de Viçosa, 2001. 301 p.

RIZZARDI, M. A. et al. Controle de plantas daninhas em milho em função de épocas de aplicação de nitrogênio. Planta Daninha, v. 26, n. 1, p. 113-121, 2008.

SILVA, P. S. L.; OLIVEIRA, F. H. T.; SILVA, P. I. B. Efeitos da aplicação de doses de nitrogênio e densidades de plantio sobre os rendimentos de espigas verdes e de grãos de milho.

Horticultura Brasileira, v. 21, n. 3, p. 454-457, 2003.

SILVA, P. S. L.; SILVA, E. S.; MESQUTTA, S. S. X. Weed control and green ear yield in maize. Planta Daninha, v. 22, n. 1, p. 137-144, 2004a.

SILVA, A. A.; VARGAS, L.; WERLANG, R. C. Manejo de plantas daninhas na cultura do milho. In: GALVÃO, J. C. C.; MIRANDA, G. V. Tecnologias de produção do milho Viçosa, MG: Universidade Federal de Viçosa, 2004b. p. $269-310$

SILVA, P. S. L. et al. Weed control via intercropping with gliricídia. I. Corn crop. Planta Daninha, v. 27, n. 1, p. 105-112, 2009.

SINGH, S. et al. Evaluation of mulching, intercropping with Sesbania and herbicide use for weed management in dry-seeded rice (Oryza sativa L.). Crop Protec., v. 26, n. 4, p. 518-524, 2007.

SPLIID, N. H.; KOEPPEN, B. Occurrence of pesticides in Danish shallow ground water. Chemosphere, v. 37, p. $1307-1316,1998$.

SUBEDI, D.K.; MA, B.L. Nitrogen uptake and partitioning in stay-green and leafy maize hybrids. Crop Sci., v. 45, n. 2, p. 740-747, 2005.

THOMAS, P. E. L.; ALLISON, J. C. S. Competition between maize and Rottboellia exaltata. J. Agric. Sci., v. 84, n. 1, p. 305-312, 1975.

TOLLENAAR, M. et al. Effects of weed interference and soil nitrogen on four maize hybrids. Agron. J., v. 86, n. 4, p. 596-601, 1994.

VETSCH, J. A.; RANDALL, G. W. Corn production as affected by nitrogen application timing and tillage. Agron.J., v. 96, n. 2, p. 502-509, 2004.

ZANATTA, F. S. et al. Influência de doses de nitrogênio na época de controle de plantas daninhas na cultura do milho (Zea mays L.). Planta Daninha, v. 25, n. 3, p. 529-536, 2007. 